Total fat as a percentage of the S carcasses increased from $13 \%$ at $9 \mathrm{~kg}$ to $25 \%$ at $24 \mathrm{~kg}$. Subcutaneous fat as a percentage of total fat was low and increased only very slightly from 31 to $35 \%$ with increasing carcass weight. A $\times \mathrm{S}$ carcasses were fatter and had a greater proportion of subcutancous fat than the $\mathrm{S}$ carcasses.

Key words : Kid, Angora, Saanen, growth, feeding, carcass.

\title{
Ralgro implants as a growth-promoter for Saanen male kids
}

\author{
S. LANDAU \\ Extension Service, Ministry of Agriculture, Yaakov, 3, 76262, Rehovot (Israël)
}

The effect of Ralgro implants ( $12 \mathrm{mg}$ Zeranol) to intact weaned male kids on growth and behaviour was investigated in two feeding experiments : in both experiments, the kids were fed a concentrate Ad libitum $(2.6 \mathrm{Mcal}$ of Metabolizable Energy, $16 \%$ Crude Protein, $1 \% \mathrm{Ca}, .45 \%$ $\mathrm{P}$, and $22 \mathrm{ppm}$ monensin-sodium, on an as-fed basis), and a daily allowance of 100 grams wheat straw. In experiment 1 , five kids were first implanted at the age of 75 days and reimplanted 42 days thereafter ; five unimplanted contemporary kids were used as control. The initial body-weight $(\mathrm{kg})$, average daily gain $(\mathrm{g} / \mathrm{d})$ on days $1-42$ and $1-70$, and feed efficiency ( $\mathrm{kg}$ concentrate $/ \mathrm{kg}$ gain) of the treatment and control groups were $12.6,252,250,3.5$ and $12.7,219,212,4.0$, respectively.

In experiment 2, 6 kids were implanted at the age of 86 days, and 6 kids served as control. All the kids were kept 30 days on experiment. The initial body-weight $(\mathrm{kg})$, average daily gain $(\mathrm{g} /$ d) and feed efficiency of the treatment and control groups were 15.7, 250, 2.9 and 14.7, 228, 3.4, respectively.

The positive effect of Ralgro on growth was significant in experiment 1 only ; no differences were found in blood urea nitrogen concentrations at three sampling dates between the Ralgro and control kids : $29.9,30.7 \mathrm{mg} / 100 \mathrm{ml}$ (1-st day on experiment) $: 22.3,22.2 \mathrm{mg} / 100 \mathrm{ml}$ (day 8 on experiment) ; 26.7, 26.1 mg/100 ml (day 30 on experiment). Ralgro implantation increased teat length in both experiments $(B<0.01)$ and teat length was found to be a practical way to distinguish implanted and non-implanted kids. Testicular circumference was not affected by the treatments.

In experiment 1 , the implanted kids spent more time sitting ( $46 \%$ vs. $35 \%$, day $10 ; 28 \%$ vs. $10 \%$, day $25 ; 74 \%$ vs. $40 \%$, day 45 ) and less time standing and jumping than the control kids $(B<0.05)$.

The rectal temperature was lower in the implanted than in the control kids $\left(39.22^{\circ} \mathrm{C}\right.$ vs. $39.67^{\circ} \mathrm{C}$, exp. $1, \mathrm{~B}<0.01 ; 39.10^{\circ} \mathrm{C}$ vs. $39.60^{\circ} \mathrm{C}$, exp. $\left.2, \mathrm{~B}<0.01\right)$ during ordinary spring days $\left(18^{\circ} \mathrm{C}, 55 \% \mathrm{RH}\right)$; during a hot-spell $\left(32.8^{\circ} \mathrm{C}, 13 \% \mathrm{RH}\right)$ not such differences were noted $\left(39.2^{\circ} \mathrm{C}\right.$ vs. $39.37^{\circ} \mathrm{C}$, exp. $1 ; 39.8^{\circ} \mathrm{C}, 39.8{ }^{\circ} \mathrm{C}$, exp. 2).

It seems that Ralgro implanting has some potential to promote growth in intact male kids fed highly energetic diets; however, this effect could be the result of several metabolic influences, as expressed by behavioural parameters and different patterns in rectal temperatures, instead of a mere anabolic effect.

Key words : Implant, growth-promoter, kid, Saanen, Ralgro. 